\title{
Study of Heavy Metal Accumulation in Sewage Irrigated Vegetables in Different Regions of Agra District, India
}

\author{
Preeti Parashar*, Fazal Masih Prasad \\ School of Chemical Sciences, Department of Chemistry, St. John's College, Agra, India. \\ Email: *preetiavn@gmail.com
}

Received January $15^{\text {th }}, 2013$; revised February $15^{\text {th }}, 2013$; accepted February $28^{\text {th }}, 2013$

\begin{abstract}
Heavy metal contamination of soil resulting from sewage irrigation is a cause of serious concern due to the potential health impacts of consuming contaminated products. In this study an assessment made of the impact of sewage irrigation on heavy metal contamination of Spinach, Cabbage, Beetroot, Reddish, Okra, Tomato, and Cucumber is widely cultivated and consumed in urban India, particularly by the poor. A field study was conducted at seven major sites that were irrigated by either treated, (Dhandupura) or untreated wastewater in the suburban areas of Agra, India. Samples of irrigation water, soil, and the edible portion of all the vegetables were collected monthly during the winter seasons and were analyzed for $\mathrm{Fe}, \mathrm{Cd}, \mathrm{Cu}, \mathrm{Zn}$, and $\mathrm{Pb}$. Heavy metals in irrigation water were below the internationally recommended (WHO) maximum permissible limits set for agricultural use for all heavy metals except $\mathrm{Cd}$ at all the sites. Similarly, the mean heavy metal concentrations in soil were below the Indian standards for all heavy metals, but the maximum value of $\mathrm{Cd}$ recorded during January was higher than the standard. However, in the edible portion of spinach, the $\mathrm{Cd}$ concentration was higher than the permissible limits of the Indian standard during summer, whereas $\mathrm{Pb}$ concentrations were higher in winter seasons. Results of correlation analysis were computed to assess the relationship between individual heavy metal concentration in the vegetable samples. The study concludes that the use of treated and untreated wastewater for irrigation has increased the contamination of $\mathrm{Cd}, \mathrm{Pb}$ in edible portion of vegetables causing potential health risk in the long term from this practice. The study also points to the fact that adherence to standards for heavy metal contamination of soil and irrigation water does not ensure safe food. Fe was measured abundant in soil whereas $\mathrm{Pb}$ and $\mathrm{Cd}$ were found more in untreated sites as compared to treated site. Correlation, paired T-test and ANOVA were also carried out for pre post harvested soil and vegetables.
\end{abstract}

Keywords: Heavy Metals; AAS; Sewage; Pearson Correlation; Paired T-Test; ANOVA

\section{Introduction}

Agra is situated in the extreme southwest corner of Uttar Pradesh, India. It stretches across $26 " 44 ' \mathrm{~N}$ to $27 " 25 ' \mathrm{~N}$ and $77^{\prime \prime 26 ' E ~ t o ~} 78^{\prime \prime} 32$ 'E. It is situated at the bank of Yamuna. It has limited forest area having sporting trees of Babul, Ber, Neem, Peepal. Agra suffers from extremities of climate with scorching hot summers and chilly winters. Like most of the cities of North India the weather and climate of Agra is extreme and tropical. In Agra and surrounding areas summers are extremely hot and the maximum temperature goes to $47^{\circ} \mathrm{C}$ while during winters it remains cold and foggy. During monsoon it becomes hot and humid. The soil, water and vegetable samples were collected during winter season in the month of December. The vegetable crops were irrigated in sewage water.

Wastewater irrigation is known to contribute signifi-

"Corresponding author. cantly to the heavy metal contents of soils [1]. Plant species have a variety of capacities in removing and accumulating heavy metals, so there are reports indicating that some species may accumulate specific heavy metals, causing a serious health risk to human health when plants based food stuff are consumed [2]. Disposal of sewage water and industrial wastes is a great problem. Often it is drained to the agricultural lands where it is used for growing crops including vegetables. These sewage effluents are considered not only a rich source of organic matter and other nutrients but also they elevate the level of heavy metals like $\mathrm{Fe}, \mathrm{Mn}, \mathrm{Cu}, \mathrm{Zn}, \mathrm{Pb}, \mathrm{Cr}, \mathrm{Ni}, \mathrm{Cd}$ and Co in receiving soils [3].

Heavy metals are one of a range of important types of contaminants that can be found on the surface and in the tissue of fresh vegetables. Prolonged human consumption of unsafe concentrations of heavy metals in foodstuffs may lead to the disruption of numerous biological and biochemical processes in the human body. Heavy metal 
accumulation gives rise to toxic concentrations in the body, while some elements (e.g. arsenic, cadmium, chromium) act as carcinogens and others (e.g. mercury and lead) are associated with developmental abnormalities in children.

Vegetables are an important part of human's diet. In addition to a potential source of important nutrients, vegetables constitute important functional food components by contributing protein, vitamins, iron and calcium which have marked health effects [4]. Vegetables, especially those of leafy vegetables grown in heavy metals contaminated soils, accumulate higher amounts of metals than those grown in uncontaminated soils because of the fact that they absorb these metals through their leaves [5]. [6] investigated the concentrations of heavy metals such as $\mathrm{Cd}$, lead $(\mathrm{Pb})$, Zinc $(\mathrm{Zn}), \mathrm{Cu}$ and $\mathrm{Ni}$ in different vegetables, grown in various parts of Turkey. The levels of heavy metals (lead, cadmium, copper and zinc) were examined in selected fruits and vegetables sold in the local markets of Egypt [7,8] studied the contents of heavy metals in vegetables grown in an industrial area of North Greece.

According to [9], Zn deficiency in plants increased iron concentration. [10] have reported generally much more pronounced toxic effect of cadmium on plant growth parameters under iron deficiency conditions than under normal iron supply.

Plant studies have shown that although zinc is an essential element for higher plants, it is considered phytotoxic in elevated concentrations, directly affecting crop yields and soil fertility. Soil concentrations range from $70-400 \mathrm{mg} / \mathrm{Kg}$. Total zinc is classified as critical, above which toxicity is considered likely [11]. Zinc is an essential element needed by our body in small amounts. We are exposed to zinc compounds in food. The average daily zinc intake through the diet ranges from 5.2 to 16.2 milligrams $($ milligram $=0.001 \mathrm{gm})$. Food may contain levels of zinc ranging from approximately 2 parts of zinc per million $(2 \mathrm{ppm})$ parts food (e.g. leafy vegetables) to $29 \mathrm{ppm}$ (meats, fish, poultry).

Cadmium and its compounds may travel through soil, but its mobility depends on several factors such as $\mathrm{pH}$ and amount of organic matter which will vary depending on the local environment. Generally cadmium binds strongly to organic matter where it will be immobile in soil and be taken up by plant life, eventually entering the food supply. Leafy vegetables like cauliflower, cabbage, spinach, etc., grow quite well in the presence of sewage water [12] whereas vegetables such as radish are sensitive to sewage water [13]. Vegetables grown by the use of sewage water contain many heavy metals, which cause serious health hazards to the community and animals as well $[14,15]$. This concern is of special importance, where un-treated sewage is applied for longer periods to grow vegetables in urban lands. Heavy metal bioaccumulation in the food chain can be especially highly dangerous to human health. These metals enter the human body mainly through two routes namely: inhalation and ingestion, and with ingestion being the main route of exposure to these elements in human population.

The aim of research is to assess the effect of heavy metal accumulation in sewage irrigated soil and vegetable crop.

\section{Method and Material}

The analysis of various parameters for the soil samples collected from the varying plots of different sites e.g. (Balkeshwar, Bichpuri, Dhandupura, Etmadpur, Gopalpura, Nunhai, Sikandra) of Agra region was conducted during the winter season before and after harvesting the various vegetable crops. The soil in Agra region is basically alluvial. The climate is neither too wet nor too dry. For the detection of heavy metals in sewage water AAS technique was used.

\subsection{Sample Preparation}

Reagents used:

1) Air: Cleaned and dried through a filter air;

2) Acetylene: Standard, commercial graded;

3) Metal free water: All the reagents and dilutions were made in metal free water;

4) Methyl isobutyl ketone (MIBK): Reagent grade MIBK is purified by redistillation before use;

5) Ammonium pyrrolidine dithiocarbonate (APDC) solution: $4 \mathrm{gm} \mathrm{APDC}$ is dissolved in $100 \mathrm{ml}$ water;

6) Conc. $\mathrm{HNO}_{3}$;

7) Standard metal solutions: Five standard solutions of $0.01,0.1,1,10$ and $100 \mathrm{mg} / \mathrm{l}$ concentrations of metals for instrument calibration and sorption study are prepared by diluting their stock solution of $1 \mathrm{gm} / 1$ i.e. $1 \mathrm{ml}=1 \mathrm{mg}$ metal.

\subsubsection{Water Samples}

The sewage water samples were collected from different sites. The samples were collected in 1-litre precleaned (with $50 \% \mathrm{HNO}_{3}$ and than thrice with deionized water) plastic bottles and acidified with $5 \mathrm{ml}$ conc. $\mathrm{HNO}_{3}$ per litre of wastewater for the analysis of heavy metals.

\subsubsection{Soil Samples}

About $0.5 \mathrm{Kg}$ composite samples from 10 - 20 sub samples were taken in plastic bags of $1 \mathrm{Kg}$ capacity by quartering technique taken in zig zag along different sections of the area until the whole area was covered. A representative composite soil sample from agricultural is made up of 10 - 20 sub samples from a uniform field. Sub samples are taken with a soil auger after cleaning ground tightly 
with wooden pestle in a wooden mortar. The composite sample is spread to be air dried and extraneous material such as leaves, twigs, rocks etc. were removed. The whole of composite sample is spread in a uniform way and go on quartering and taking diagonal quarters rejecting the other too till approximately $500 \mathrm{gm}$ soil sample is obtained. The sample is filtered through a $2 \mathrm{~mm}$ plastic sieve. About $0.5 \mathrm{Kg}$ filtered soil sample was stored in a clean polythene bag with proper labelling for analysis.

\subsubsection{Vegetable Samples}

Plant samples were collected in paper bags. Each sample was given a particular identification number. The collected plant samples were washed with distilled water, wiped and dried in oven at $60^{\circ} \mathrm{C}$ and ground in a micro grinding mill and stored.

The heavy metal analysis is done to detect heavy metals in water, soil and vegetable samples.

\subsection{Statistical Analysis}

Descriptive statistical analysis including 2-way ANOVA, pearson correlation, significance $(0.01$ and 0.05$)$ was done by SPSS software.

\section{Results and Discussion}

Sewage contained on an average $1.20 \mathrm{mg} \cdot \mathrm{Kg}^{-1} \mathrm{Cd}$, over 8 times the permissible level by the EU standards $(0.2$ $\mathrm{mg} \cdot \mathrm{Kg}^{-1}$ ); Cu concentrations were $29.07 \mathrm{mg} \cdot \mathrm{Kg}^{-1}$, which is little higher than EU Standard $\left(20 \mathrm{mg} \cdot \mathrm{Kg}^{-1}\right)$; concentrations of $\mathrm{Pb}$ were $6.77 \mathrm{mg} \cdot \mathrm{Kg}^{-1}$, over 22 times the permissible levels allowed by both EU standards and UK guidelines $\left(0.3 \mathrm{mg} \cdot \mathrm{Kg}^{-1}\right) ; \mathrm{Zn}$ concentrations were 221 $\mathrm{mg} \cdot \mathrm{Kg}^{-1}$, over 4 times the guideline value $\left(50 \mathrm{mg} \cdot \mathrm{Kg}^{-1}\right)$. All the plants contained concentrations of heavy metals above the permissible levels. Furthermore the concentrations observed in this study were higher than those reported by other workers who have examined vegetation from other contaminated sites. The plants grown on the soil polluted with sewage-effluents were found to record higher uptake of heavy metals when compared to plants grown on normal soils [16]. The Fe concentration in sewage is high as soil in Agra is alluvial and has capacity to absorb iron. $\mathrm{Cd}$ and $\mathrm{Pb}$ content is also high in sewage. $\mathrm{Zn}, \mathrm{Cu}$ and $\mathrm{Cd}$ were highly significant $(\mathrm{p}<0.01)$ (Table 1). The treated site (Dhandupura) has comparatively lower amount of $\mathrm{Cd}$ as compared to other sites. In pre and post harvested soil $\mathrm{Fe}, \mathrm{Zn}, \mathrm{Pb}, \mathrm{Cu}$ and $\mathrm{Cd}$ are highly significant ( $\mathrm{p}<0.01$ ) (Tables 2 and 3 ). $\mathrm{Cu}$ is negatively correlated to $\mathrm{Cd}$ concentration in all the vegetables and vice versa (Table 4).

The Fe content in sewage, pre and post harvested soil post $<$ pre $<$ sewage, Zn content post $<$ pre $<$ sewage, $\mathrm{Pb}$ content sewage $<$ post $<$ pre, $\mathrm{Cu}$ content sewage $<$ pre $<$ post, Cd content sewage $<$ post $<$ pre.

The Fe content in vegetables tomato $<$ okra $<$ brinjal

Table 1. Showing ANOVA for comparison of heavy metals of different sites of sewage.

\begin{tabular}{|c|c|c|c|c|c|c|c|}
\hline & Between sites & 0.915 & 6 & 0.152 & 2.104 & 0.078 & $*$ \\
\hline \multirow[t]{3}{*}{$\mathrm{Fe}$} & Error & 2.537 & 35 & 0.072 & & & \\
\hline & Total & 3.451 & 41 & & & & \\
\hline & Between sites & 2347.682 & 6 & 391.280 & 15.640 & 0.000 & $* *$ \\
\hline \multirow{2}{*}{$\mathrm{Zn}$} & Total & 3223.326 & 41 & & & & \\
\hline & Between sites & 355.420 & 6 & 59.237 & 4.178 & 0.003 & $* *$ \\
\hline \multirow[t]{3}{*}{$\mathrm{Pb}$} & Error & 496.231 & 35 & 14.178 & & & \\
\hline & Total & 851.651 & 41 & & & & \\
\hline & Between sites & 924.134 & 6 & 154.022 & 9.106 & 0.000 & $* *$ \\
\hline \multirow[t]{3}{*}{$\mathrm{Cu}$} & Error & 591.994 & 35 & 16.914 & & & \\
\hline & Total & 1516.128 & 41 & & & & \\
\hline & Between sites & 1.099 & 6 & 0.183 & 1.576 & 0.183 & NS \\
\hline \multirow[t]{2}{*}{$\mathrm{Cd}$} & Within error & 4.067 & 35 & 0.116 & & & \\
\hline & Total & 5.165 & 41 & & & & \\
\hline
\end{tabular}


Table 2. Showing ANOVA for comparison of heavy metals of different site in pre harvested soil.

\begin{tabular}{|c|c|c|c|c|c|c|c|}
\hline & Between sites & 2.381 & 6 & 0.397 & 5.016 & 0.001 & ** \\
\hline \multirow[t]{3}{*}{$\mathrm{Fe}$} & Error & 2.769 & 35 & 0.079 & & & \\
\hline & Total & 5.150 & 41 & & & & \\
\hline & Between sites & 1665.300 & 6 & 277.550 & 7.471 & 0.000 & ** \\
\hline \multirow[t]{3}{*}{$\mathrm{Zn}$} & Error & 1300.320 & 35 & 37.152 & & & \\
\hline & Total & 2965.621 & 41 & & & & \\
\hline & Between sites & 2010.395 & 6 & 335.066 & 20.570 & 0.000 & ** \\
\hline \multirow[t]{3}{*}{$\mathrm{Pb}$} & Error & 570.124 & 35 & 16.289 & & & \\
\hline & Total & 2580.519 & 41 & & & & \\
\hline & Between sites & 3279.855 & 6 & 546.642 & 26.801 & 0.000 & ** \\
\hline \multirow[t]{3}{*}{$\mathrm{Cu}$} & Error & 713.883 & 35 & 20.397 & & & \\
\hline & Total & 3993.737 & 41 & & & & \\
\hline & Between sites & 7.305 & 6 & 1.217 & 5.185 & 0.001 & ** \\
\hline \multirow[t]{2}{*}{$\mathrm{Cd}$} & Error & 8.219 & 35 & 0.235 & & & \\
\hline & Total & 15.524 & 41 & & & & \\
\hline
\end{tabular}

Table 3. Showing ANOVA for comparison of heavy metals of different site in post harvested soil.

\begin{tabular}{|c|c|c|c|c|c|c|}
\hline & Between groups & 1.949 & 6 & 0.325 & 4.674 & $0.001^{* *}$ \\
\hline \multirow[t]{3}{*}{$\mathrm{Fe}$} & Within groups & 2.432 & 35 & 0.069 & & \\
\hline & Total & 4.381 & 41 & & & \\
\hline & Between groups & 860.047 & 6 & 143.341 & 7.283 & $0.000^{* *}$ \\
\hline \multirow[t]{3}{*}{$\mathrm{Zn}$} & Within groups & 688.826 & 35 & 19.681 & & \\
\hline & Total & 1548.873 & 41 & & & \\
\hline & Between groups & 1336.214 & 6 & 222.702 & 11.949 & $0.000^{* *}$ \\
\hline \multirow[t]{3}{*}{$\mathrm{Pb}$} & Within groups & 652.336 & 35 & 18.638 & & \\
\hline & Total & 1988.550 & 41 & & & \\
\hline & Between groups & 4572.126 & 6 & 762.021 & 69.481 & $0.000^{* *}$ \\
\hline \multirow[t]{3}{*}{$\mathrm{Cu}$} & Within groups & 383.858 & 35 & 10.967 & & \\
\hline & Total & 4955.983 & 41 & & & \\
\hline & Between groups & 5.851 & 6 & 0.975 & 5.695 & $0.000^{* *}$ \\
\hline \multirow[t]{2}{*}{$\mathrm{Cd}$} & Within groups & 5.993 & 35 & 0.171 & & \\
\hline & Total & 11.843 & 41 & & & \\
\hline
\end{tabular}


and cucumber $<$ reddish $<$ spinach and beetroot, Zn content as brinjal and copper $<$ okra $<$ tomato $<$ reddish $<$ spinach $<$ beetroot $<\mathrm{Pb}$ content as tomato $<$ okra $<$ brinjal and cucumber $<$ reddish $<$ beetroot $<$ spinach. $\mathrm{Cu}$ as okra $<$ tomato $<$ cucumber $<$ brinjal $<$ reddish $<$ spinach $<$ beetroot $\mathrm{Cd}$ as okra $<$ brinjal and cucumber $<$ tomato $<$ reddish $<$ beetroot $<$ spinach. The mean values and range of heavy metals in sewage pre and post harvested soil and vegetables are shown in Tables 5-7. In sewage $\mathrm{Zn}$, $\mathrm{Pb}$ and $\mathrm{Cu}$ were highly significant W.R.T different sites. Shown in Table 1. All the heavy metals in pre and post harvested soil were highly significant W.R.T different sites. Shown in Tables 2 and 3. The correlation between vegetables and sites was calculated through pearson correlation. $\mathrm{Fe}$ is highly significant with $\mathrm{Zn}, \mathrm{Cu}$ and $\mathrm{Cd}$ of different sites. $\mathrm{Cu}$ is negatively correlated with $\mathrm{Cd}(\mathrm{r}=$ -0.009 ) shown in Table 4.

The conc. of heavy metals in sewage and soil is shown in Figure 1. It is concluded from the figure that $\mathrm{Zn}$ concentration is highest in sewage. It is also clear that pre harvested soil accumulates more heavy metals as compared to post harvested soil. Cd is accumulated in traces in sewage as well as soil. (Figure 1). Spinach, reddish and beetroot are more prone to absorb more heavy metals from soil (Figure 2).

The heavy metal content in Akaki water (Ni-12.1, $\mathrm{Cu}-38.4, \mathrm{~Pb}-35.5$ and $\left.\mathrm{Cd}-2.5 \mu \mathrm{g} \cdot \mathrm{L}^{-1}\right)[17]$ was higher than the natural elemental levels in freshwater [18].

\section{Conclusion and Recommendation}

From the study it is revealed that, untreated sewage and industrial effluents are the main source of pollution to soil and irrigation with contaminated sewage water containing variable amounts of heavy metals leads to increase in concentration of metals in soil and vegetables, which is grown using the polluted water. Concentration of metals in vegetables will provide baseline data and there is a need for intensive sampling for quantification of results throughout the country. Since cucumber is the least accumulator of metals and metalloids, it may be less risky to eat cucumber than eating beetroot and spinach, from health standpoint. To avoid entrance of metals into the food chain, municipal or industrial waste should not

Table 4. Correlation between different components of vegetable in different sites.

\begin{tabular}{|c|c|c|c|c|c|c|}
\hline Component & (r) & $\mathrm{Fe}$ & $\mathrm{Zn}$ & $\mathrm{Pb}$ & $\mathrm{Cu}$ & $\mathrm{Cd}$ \\
\hline \multirow[t]{2}{*}{$\mathrm{Fe}$} & Pearson corr. & 1 & $0.414^{* *}$ & 0.207 & $0.396^{* *}$ & $0.308^{*}$ \\
\hline & Sig. & & 0.003 & 0.154 & 0.005 & 0.032 \\
\hline \multirow[t]{2}{*}{$\mathrm{Zn}$} & Pearson corr. & $0.414^{* *}$ & 1 & 0.192 & 0.092 & $0.363^{*}$ \\
\hline & Sig. & 0.003 & & 0.187 & 0.531 & 0.010 \\
\hline \multirow[t]{2}{*}{$\mathrm{Pb}$} & Pearson corr. & 0.207 & 0.192 & 1 & 0.078 & $0.368^{* *}$ \\
\hline & Sig. & 0.154 & 0.187 & & 0.597 & 0.009 \\
\hline \multirow[t]{2}{*}{$\mathrm{Cu}$} & Pearson corr. & $0.396^{* *}$ & 0.092 & 0.078 & 1 & -0.009 \\
\hline & Sig. & 0.005 & 0.531 & 0.597 & & 0.954 \\
\hline $\mathrm{Cd}$ & Pearson corr. & $0.308^{*}$ & $0.363^{*}$ & $0.368^{* *}$ & -0.009 & 1 \\
\hline
\end{tabular}

Table 5. Showing heavy metal conc. $\left(\mathrm{mg} \cdot \mathrm{Kg}^{-1}\right)$ in sewage water of different sites.

\begin{tabular}{|c|c|c|c|c|c|c|c|c|}
\hline $\begin{array}{c}\text { Sewage water } \\
\text { (Heavy metals) }\end{array}$ & 1 & 2 & 3 & 4 & 5 & 6 & 7 & $\begin{array}{l}\text { Overall } \\
\text { average }\end{array}$ \\
\hline Iron (\%) & $\begin{array}{c}0.98-1.9 \\
(1.21)\end{array}$ & $\begin{array}{l}0.97-1.17 \\
(1.05)\end{array}$ & $\begin{array}{l}0.87-1.43 \\
(1.11)\end{array}$ & $\begin{array}{l}0.93-1.12 \\
(1.03)\end{array}$ & $\begin{array}{l}1.23-1.76 \\
(1.43)\end{array}$ & $\begin{array}{c}1.09-1.89 \\
(1.4)\end{array}$ & $\begin{array}{c}0.9-1.99 \\
(1.2)\end{array}$ & $\begin{array}{l}0.87-1.99 \\
(1.20)\end{array}$ \\
\hline $\begin{array}{c}\mathrm{Zinc} \\
\left(\mathrm{mg} \cdot \mathrm{Kg}^{-1}\right)\end{array}$ & $\begin{array}{c}45.34-60.11 \\
(53.49)\end{array}$ & $\begin{array}{c}56.56-71.78 \\
(63.27)\end{array}$ & $\begin{array}{c}49.9-57.76 \\
(53.82)\end{array}$ & $\begin{array}{c}65.87-78.98 \\
(71.82)\end{array}$ & $\begin{array}{c}56.78-76.76 \\
(70.4)\end{array}$ & $\begin{array}{c}54.76-61.67 \\
(57.93)\end{array}$ & $\begin{array}{c}65.71-73.56 \\
\quad(70.64)\end{array}$ & $\begin{array}{c}45.34-78.98 \\
\quad(63.05)\end{array}$ \\
\hline$\underset{\left(\mathrm{mg} \cdot \mathrm{Kg}^{-1}\right)}{\text { Lead }}$ & $\begin{array}{c}21.0-32.66 \\
(29.12)\end{array}$ & $\begin{array}{c}30.43-40.78 \\
(35.06)\end{array}$ & $\begin{array}{c}30.13-37.87 \\
(32.95)\end{array}$ & $\begin{array}{c}32.65-40.43 \\
(36.78)\end{array}$ & $\begin{array}{c}23.76-39.76 \\
(30.91)\end{array}$ & $\begin{array}{c}28.54-36.01 \\
\quad(32.27)\end{array}$ & $\begin{array}{c}23.73-29.32 \\
(27.92)\end{array}$ & $\begin{array}{c}21.0-40.78 \\
(32.14)\end{array}$ \\
\hline $\begin{array}{c}\text { Copper } \\
\left(\mathrm{mg} \cdot \mathrm{Kg}^{-1}\right)\end{array}$ & $\begin{array}{c}29.09-32.87 \\
(30.98)\end{array}$ & $\begin{array}{c}25.9-35.76 \\
(30.15)\end{array}$ & $\begin{array}{c}17.34-29.02 \\
(24.45)\end{array}$ & $\begin{array}{c}28.76-40.64 \\
(35.72)\end{array}$ & $\begin{array}{c}19.09-29.54 \\
(22.07)\end{array}$ & $\begin{array}{c}30.13-39.23 \\
(34.1)\end{array}$ & $\begin{array}{l}21.54-30.1 \\
\quad(26.02)\end{array}$ & $\begin{array}{c}17.34-40.64 \\
(29.07)\end{array}$ \\
\hline $\begin{array}{l}\text { Cadmium } \\
\left(\mathrm{mg} \cdot \mathrm{Kg}^{-1}\right)\end{array}$ & $\begin{array}{c}0.84-1.78 \\
\quad(1.13)\end{array}$ & $\begin{array}{c}0.67-1.75 \\
\quad(1.02)\end{array}$ & $\begin{array}{c}0.54-1.2 \\
(0.94)\end{array}$ & $\begin{array}{c}0.98-1.9 \\
(1.34)\end{array}$ & $\begin{array}{c}1.1-2.01 \\
(1.49)\end{array}$ & $\begin{array}{c}0.98-1.52 \\
(1.2)\end{array}$ & $\begin{array}{c}0.67-1.92 \\
(1.15)\end{array}$ & $\begin{array}{l}0.54-2.01 \\
\quad(1.18)\end{array}$ \\
\hline
\end{tabular}


Table 6. Showing heavy metal conc. $\left(\mathrm{mg} \cdot \mathrm{Kg}^{-1}\right)$ in pre harvested soil of different sites.

\begin{tabular}{|c|c|c|c|c|c|c|c|c|}
\hline $\begin{array}{l}\text { Heavy metals } \\
\quad \text { in soil }\end{array}$ & 1 & 2 & 3 & 4 & 5 & 6 & 7 & Overall range \\
\hline Iron $(\%)$ & $\begin{array}{c}0.9-2.01 \\
\quad(1.41)\end{array}$ & $\begin{array}{c}0.99-1.9 \\
(1.42)\end{array}$ & $\begin{array}{c}0.54-0.73 \\
(0.68)\end{array}$ & $\begin{array}{c}0.87-1.61 \\
\quad(1.23)\end{array}$ & $\begin{array}{c}0.98-1.61 \\
\quad(1.24)\end{array}$ & $\begin{array}{c}0.9-1.19 \\
(1.07)\end{array}$ & $\begin{array}{c}0.89-1.26 \\
(1.05)\end{array}$ & $\begin{array}{c}0.54-2.01 \\
\quad(1.15)\end{array}$ \\
\hline $\begin{array}{c}\text { Zinc } \\
\left(\mathrm{mg} \cdot \mathrm{Kg}^{-1}\right)\end{array}$ & $\begin{array}{c}45.76-55.09 \\
(49.69)\end{array}$ & $\begin{array}{c}48.03-58.98 \\
\quad(53.71)\end{array}$ & $\begin{array}{c}47.61-54.9 \\
(50.32)\end{array}$ & $\begin{array}{c}47.69-76.43 \\
(62.29)\end{array}$ & $\begin{array}{c}42.6-63.6 \\
(55.23)\end{array}$ & $\begin{array}{c}47.9-54.16 \\
(50.11)\end{array}$ & $\begin{array}{c}62.19-70.69 \\
(67.27)\end{array}$ & $\begin{array}{c}42.6-76.43 \\
(55.51)\end{array}$ \\
\hline $\begin{array}{c}\text { Lead } \\
\left(\mathrm{mg} \cdot \mathrm{Kg}^{-1}\right)\end{array}$ & $\begin{array}{c}34.9-46.98 \\
(41.19)\end{array}$ & $\begin{array}{c}35.76-43.98 \\
(39.41)\end{array}$ & $\begin{array}{c}21.66-36.94 \\
(28.7)\end{array}$ & $\begin{array}{c}24.36-31.93 \\
(28.45)\end{array}$ & $\begin{array}{c}21.65-36.0 \\
\quad(27.1)\end{array}$ & $\begin{array}{c}17.21-24.64 \\
(20.93)\end{array}$ & $\begin{array}{c}20.17-29.79 \\
(24.85)\end{array}$ & $\begin{array}{c}17.21-46.98 \\
(30.09)\end{array}$ \\
\hline $\begin{array}{c}\text { Copper } \\
\left(\mathrm{mg} \cdot \mathrm{Kg}^{-1}\right)\end{array}$ & $\begin{array}{c}29.04-40.32 \\
(35.42)\end{array}$ & $\begin{array}{c}29.76-48.2 \\
\quad(40.62)\end{array}$ & $\begin{array}{c}16.69-18.96 \\
(17.78)\end{array}$ & $\begin{array}{c}16.72-21.93 \\
(19.44)\end{array}$ & $\begin{array}{c}12.34-18.98 \\
(15.32)\end{array}$ & $\begin{array}{c}22.96-36.19 \\
(30.19)\end{array}$ & $\begin{array}{c}16.94-32.8 \\
(24.55)\end{array}$ & $\begin{array}{c}12.34-48.2 \\
(26.18)\end{array}$ \\
\hline $\begin{array}{l}\text { Cadmium } \\
\left(\mathrm{mg} \cdot \mathrm{Kg}^{-1}\right)\end{array}$ & $\begin{array}{c}0.92-2.98 \\
(1.33)\end{array}$ & $\begin{array}{c}0.8-1.65 \\
(1.09)\end{array}$ & $\begin{array}{c}0.07-0.32 \\
(0.22)\end{array}$ & $\begin{array}{c}0.29-1.61 \\
(0.79)\end{array}$ & $\begin{array}{c}0.36-2.41 \\
(1.59)\end{array}$ & $\begin{array}{c}0.22-1.01 \\
(0.7)\end{array}$ & $\begin{array}{c}0.56-1.07 \\
(0.76)\end{array}$ & $\begin{array}{c}0.07-2.98 \\
(0.92)\end{array}$ \\
\hline
\end{tabular}

Table 7. Showing heavy metal conc. $\left(\mathrm{mg} \cdot \mathrm{Kg}^{-1}\right)$ in post harvested soil of different sites.

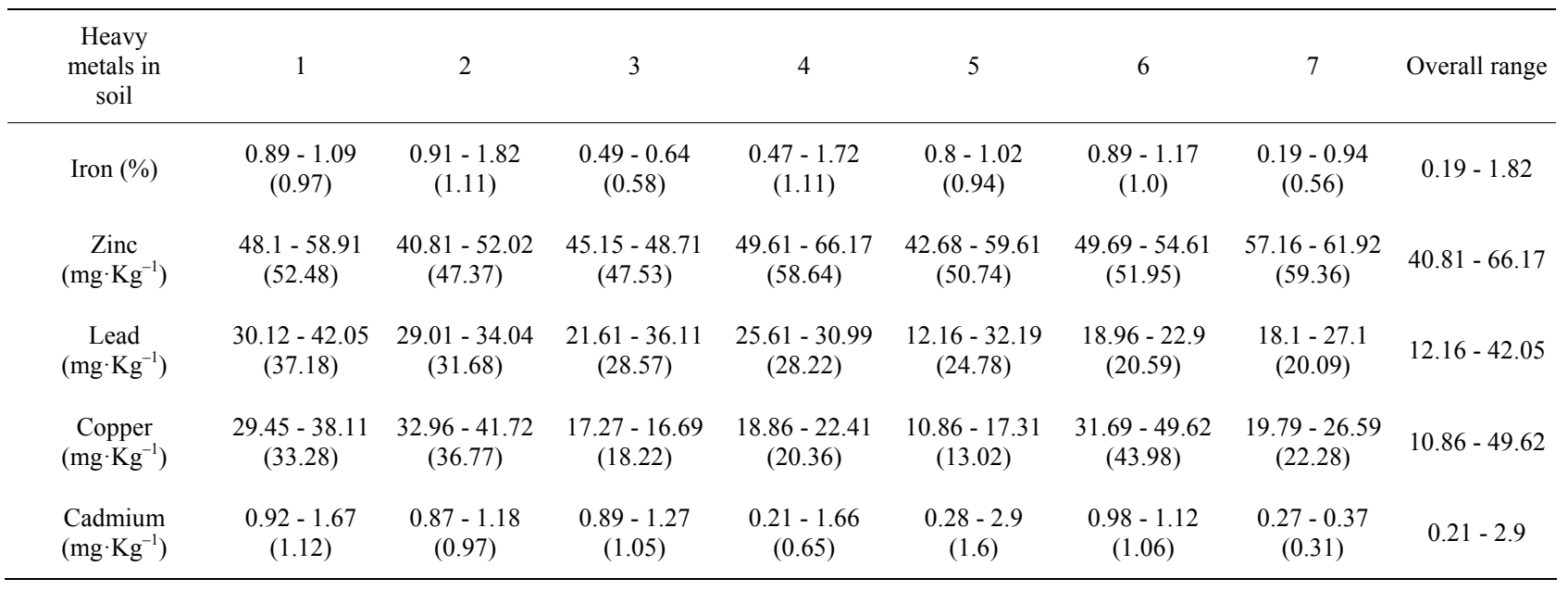

Table 8. Showing heavy metal conc. $\left(\mathrm{mg} \cdot \mathrm{Kg}^{\mathrm{s}}\right)$ in vegetables of different sites.

\begin{tabular}{|c|c|c|c|c|c|}
\hline Heavy metals in veg. & $\mathrm{Fe}(\%)\left(\mathrm{mg} \cdot \mathrm{Kg}^{-1}\right)$ & $\mathrm{Zn}\left(\mathrm{mg} \cdot \mathrm{Kg}^{-1}\right)$ & $\mathrm{Pb}\left(\mathrm{mg} \cdot \mathrm{Kg}^{-1}\right)$ & $\mathrm{Cu}\left(\mathrm{mg} \cdot \mathrm{Kg}^{-1}\right)$ & $\mathrm{Cd}\left(\mathrm{mg} \cdot \mathrm{Kg}^{-1}\right)$ \\
\hline Spinach & $\begin{array}{c}0.92-1.98 \\
(1.38)\end{array}$ & $\begin{array}{c}54.12-71.89 \\
(63.91)\end{array}$ & $\begin{array}{c}25.76-36.98 \\
\quad(31.42)\end{array}$ & $\begin{array}{c}18.35-39.56 \\
(24.72)\end{array}$ & $\begin{array}{c}0.14-1.98 \\
\quad(1.09)\end{array}$ \\
\hline Brinjal & $\begin{array}{c}(0.61-1.09) \\
(0.91)\end{array}$ & $\begin{array}{c}49.09-60.12 \\
(53.92)\end{array}$ & $\begin{array}{c}20.12-32.56 \\
\quad(27.76)\end{array}$ & $\begin{array}{c}15.23-31.35 \\
(20.89)\end{array}$ & $\begin{array}{c}0.12-0.97 \\
(0.47)\end{array}$ \\
\hline Cucumber & $\begin{array}{c}0.61-1.09 \\
(0.87)\end{array}$ & $\begin{array}{c}50.12-60.12 \\
\quad(54.84)\end{array}$ & $\begin{array}{c}20.12-32.56 \\
\quad(26.27)\end{array}$ & $\begin{array}{c}15.23-29.56 \\
(20.38)\end{array}$ & $\begin{array}{c}0.12-0.97 \\
(0.5)\end{array}$ \\
\hline Reddish & $\begin{array}{c}0.9-1.9 \\
(1.12)\end{array}$ & $\begin{array}{c}53.12-70.12 \\
(60.84)\end{array}$ & $\begin{array}{c}23.06-34.26 \\
(28.99)\end{array}$ & $\begin{array}{c}18.45-38.67 \\
(24.35)\end{array}$ & $\begin{array}{c}0.19-1.52 \\
(0.87)\end{array}$ \\
\hline Beetroot & $\begin{array}{c}0.99-1.98 \\
(1.4)\end{array}$ & $\begin{array}{c}54.89-71.98 \\
(63.03)\end{array}$ & $\begin{array}{c}23.98-36.23 \\
(30.93)\end{array}$ & $\begin{array}{c}19.01-40.13 \\
(24.95)\end{array}$ & $\begin{array}{c}0.17-1.9 \\
\quad(1.3)\end{array}$ \\
\hline Tomato & $\begin{array}{c}0.69-0.97 \\
(0.86)\end{array}$ & $\begin{array}{c}49.78-69.03 \\
(59.25)\end{array}$ & $\begin{array}{c}19.23-30.12 \\
(24.51)\end{array}$ & $\begin{array}{c}16.23-29.12 \\
(21.31)\end{array}$ & $\begin{array}{c}0.12-0.98 \\
(0.61)\end{array}$ \\
\hline Okra & $\begin{array}{c}0.26-0.98 \\
(0.72)\end{array}$ & $\begin{array}{c}48.67-62.87 \\
(48.67)\end{array}$ & $\begin{array}{c}18.34-31.23 \\
(23.34)\end{array}$ & $\begin{array}{c}16.45-25.3 \\
(19.64)\end{array}$ & $\begin{array}{c}0.19-0.89 \\
(0.68)\end{array}$ \\
\hline
\end{tabular}




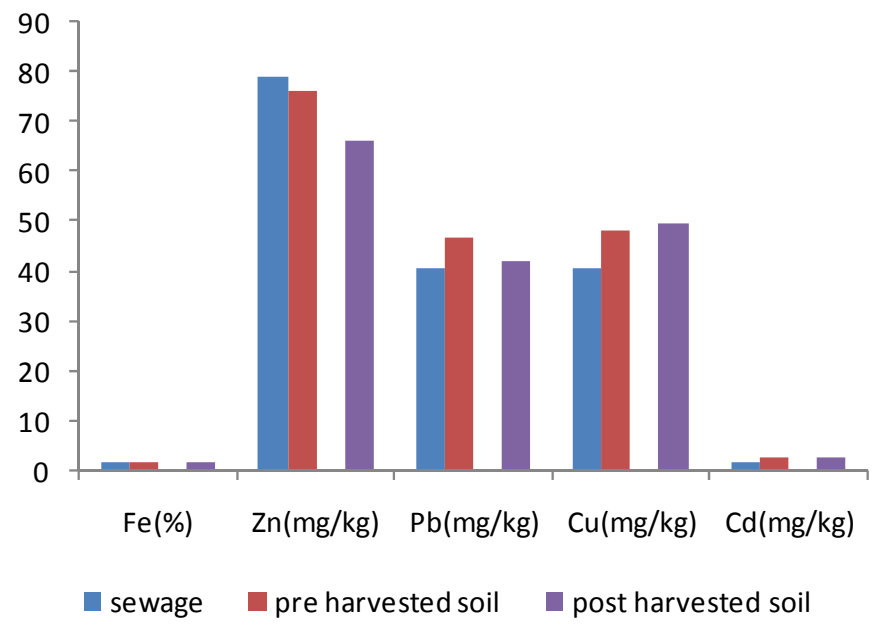

Figure 1. Showing comparison of conc. of heavy metals in sewage, pre and post harvested soil.

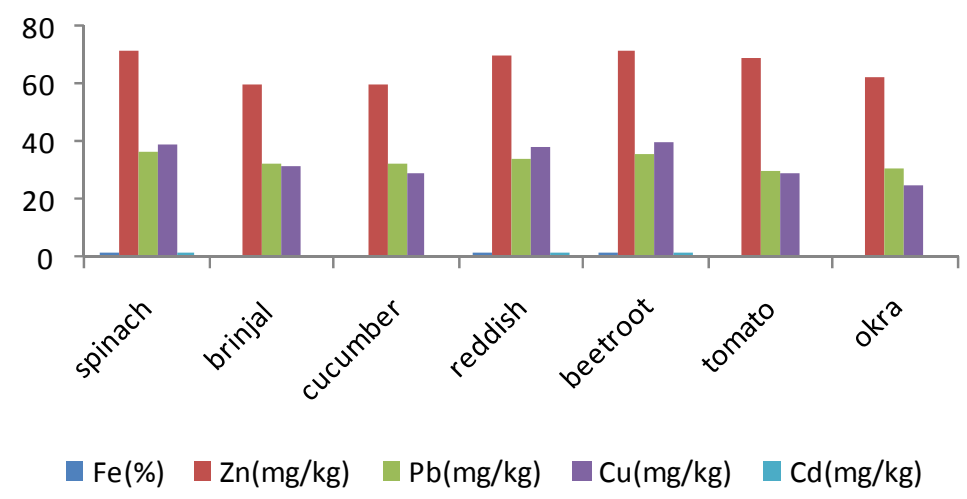

Figure 2. Showing comparison of conc. of heavy metals in various vegetables.

be drained into rivers and farmlands without prior treatment. Apart from treating the discharge that enters into the farms, it is also imperative to utilize alternative measures of cleaning up the already contaminated substrates. Continuous monitoring of soil, plant and water quality together with prevention of metals entering vegetables is a prerequisite in order to prevent potential health hazards to human beings.

\section{REFERENCES}

[1] F. Mapanda, E. N. Mangwayana, J. Nyamangara and K. E. Giller, "The Effect of Long-Term Irrigation Using Wastewater on Heavy Metal Contents of Soils under Vegetables in Harare, Zimbabwe," Agriculture, Ecosystems \& Environment, Vol. 107, 2005, pp. 151-165. doi:10.1016/j.agee.2004.11.005

[2] W. Wenzel, and F. Jackwer, "Accumulation of Heavy Metals in Plants Grown on Mineralized Solids of the Austrian Alps," Environmental Pollution, Vol. 104, No. 1, 1999, pp. 145-155. doi:10.1016/S0269-7491(98)00139-0

[3] K. P. Singh, D. Mohon, S. Sinha and R. Dalwani, "Impact Assessment of Treated/Untreated Waste Water Toxicants Discharge by Sewage Treatment Plants on Health, Agri- cultural and Environmental Quality in Waste Water Disposal Area," Chemosphere, Vol. 55, No. 2, 2004, pp. 227-255. doi:10.1016/j.chemosphere.2003.10.050

[4] S. Arai, "Global View on Functional Foods: Asian Perspectives," British Journal of Nutrition, Vol. 88, Suppl. 2, 2002, pp. S139-S143.

[5] M. S. Al Jassir, A. Shaker and M. A. Khaliq, "Deposition of Heavy Metals on Green Leafy Vegetables Sold on Roadsides of Riyadh City, Saudi Arabea," Bulletin of Environmental Contamination and Toxicology, Vol. 75, No. 5, 2005, pp. 1020-1027. doi:10.1007/s00128-005-0851-4

[6] D. Demirezen and A. Ahmet, "Heavy Metal Levels in Vegetables in Turkey Are within Safe Limits for $\mathrm{Cu}, \mathrm{Zn}$, $\mathrm{Ni}$ and Exceeded for Cd and Pb," Journal of Food Quality, Vol. 29, No. 3, 2006, pp. 252-265. doi:10.1111/j.1745-4557.2006.00072.x

[7] M. A. Radwan and K. A. Salama, "Market Basket Survey for Some Heavy Metals in Egyptian Fruits and Vegetables," Food and Chemical Toxicology, Vol. 44, No. 8, 2006, pp. 1273-1278. doi:10.1016/j.fct.2006.02.004

[8] K. Fytianos, G. Katsianis, P. Triantafyllou and G. Zachariadis, "Accumulation of Heavy Metals in Vegetables Grown in an Industrial Area in Relation to Soil," Bulletin of Environmental Contamination and Toxicology, Vol. 67, 
No. 3, 2001, pp. 423-430. doi:10.1007/s001280141

[9] I. Cakmak, "Possible Roles of Zinc in Protecting Plant Cells from Damage by Reactive Oxygen Species," New Phytologist, Vol. 146, No. 2, 2000, pp. 185-205. doi:10.1046/j.1469-8137.2000.00630.x

[10] A. Siedlecka and Z. Krupa, "Interaction between Cadmium and Iron. Accumulation and Distributionof Metals and Changes in Growth Parameters of Phaseolus Vulgaris L. Seedlings," Acta Societatis Botanicorum Poloniae, Vol. 65, No. 3-4, 1996, pp. 277-282.

[11] B. J. Alloway, A. P. Jackson and H. Morgan, "The Accumulation of Cadmium by Vegetables Grown on Soils Contaminated from a Variety of Sources," Science of the Total Environment, Vol. 91, 1990, pp. 223-236. doi:10.1016/0048-9697(90)90300-J

[12] B. Nrgholi, "Investigation of the Firoza Bad Waste Water Quality-Quantity Variation for Agricultural Use," Final Report, Iranian Agriculture Engineering Research Institute, Karaj, 2007.

[13] G. Ellen, J. W. Loon and K. Tolsma, "Heavy Metals in Vegetables Grown in the Netherlands and in Domestic and Imported Fruits," Z Lebensm Unters Forsch, Vol. 190, No. 1, 1990, pp. 34-39. doi:10.1007/BF01188261
[14] M. Qadir, A. Ghafoor, S. I. Hssain, G. Murtaza and T. Mahmood, "Copper Concentration in City Effluents Irrigated Soils and Vegetables," Pakistan Journal of Soil Science, 1999, pp. 91-102.

[15] M. Mostachari, "Investigation of Qazvin Soils and Plants Pollution with Heavy Metals during Irrigation with Waste Water," Proceeding of 75 Water and Soil Conference, Persian, 2002.

[16] T. Adhikari, M. C. Manna, M. V. Singh and R. H. Wanjari, "Bioremediation Measure to Minimize Heavy Metals Accumulation in Soils and Crops Irrigated with City Effluent Food," Agriculture \& Environment, Vol. 2, No. 1, 2004, pp. 266-270.

[17] P. C. Prabu, "Impact of Heavy Metal Contamination of Akaki River of Ethiopia on Soil and Metal Toxicity on Cultivated Vegetable Crops," Electronic Journal of Environmental Agricultural and Food Chemistry, Vol. 8, No. 9, 2009, pp. 818-827.

[18] H. Lokeshwari and G. T. Chandrappa, "Imapct of Heavy Metal Contamination of Bellandur Lake on Soil and Cultivated Vegetation," Current Science, Vol. 91, No. 5, 2006, pp. 622-627. 